\title{
PAPERS
}

\section{Mucin gene expression in Barrett's oesophagus: an in situ hybridisation and immunohistochemical study}

\author{
G S Arul, M Moorghen, N Myerscough, D A Alderson, R D Spicer, A P Corfield
}

\begin{abstract}
Background and aims-Mucin genes are expressed in a site specific manner throughout the gastrointestinal tract. Little is known about the expression pattern in the oesophagus. In this study we have investigated MUC gene expression in both the normal oesophagus and specialised intestinal metaplasia (Barrett's oesophagus).
\end{abstract}

Patients-Archived paraffin embedded material from eight specimens of normal oesophagus, 18 Barrett's oesophagus, eight gastric metaplasia, six high grade dysplasia, and six cases of adenocarcinoma were examined for expression of the mucin genes MUC1-6.

Methods-Mucin mRNA was detected by in situ hybridisation using $\left[{ }^{35} \mathrm{~S}\right]$ dATP labelled oligonucleotide probes. Mucin core protein was detected by immunohistochemistry.

Results-Normal oesophagus expressed MUC5B in the submucosal glands and MUC1 and MUC4 in the stratified squamous epithelium. Barrett's oesophagus strongly expressed MUC5AC and MUC3 in the superficial columnar epithelium, MUC2 in the goblet cells, and MUC6 in the glands. In high grade dysplasia and adenocarcinoma there was downregulation of MUC2, MUC3, MUC5AC, and MUC6, but upregulation of MUC1 and MUC4 in half of the specimens examined. Conclusions-Normal oesophagus and Barrett's oesophagus have a novel pattern of mucin gene expression. Barrett's oesophagus expressed the mucins associated with normal gastric epithelium and normal intestinal epithelium. While most mucin genes were downregulated in severely dysplastic and neoplastic tissues, there was upregulation of the membrane bound mucins MUC1 and MUC4. This may prove useful in detecting early signs of progression to adenocarcinoma of the oesophagus.

(Gut 2000;47:753-761)

Keywords: mucins; mucin gene expression; Barrett's oesophagus
The epithelial lining of the oesophagus is protected and lubricated by a thin layer of mucus that is thought to be secreted by the salivary glands and submucosal glands of the oesophagus. ${ }^{12}$ The viscoelastic properties of this layer are primarily governed by large molecular weight glycoproteins (mucins). ${ }^{3}$ Histochemistry shows that the oesophageal submucosal glands are rich in neutral, sialated, and sulphated mucins. ${ }^{1}$ The oesophagus has been shown to increase secretion of mucins from the submucosal glands in response to stimulation by gastric acid. ${ }^{45}$ Furthermore, Namiot et al have shown that oesophageal mucin secretion is significantly reduced in patients with reflux oesophagitis. $^{5}$

Each region of the gastrointestinal tract has characteristic functional requirements and the properties of the mucus produced at each site are adapted to cope with these functions. ${ }^{3}$ The mucin gene family (termed MUC1-6) comprises at least seven members, each characterised by variable number tandem repeat domains rich in serine, threonine, and proline which carry the $O$-linked oligosaccharides characteristic for these high molecular weight glycoproteins. ${ }^{67}$ These mucins can be divided broadly into two groups: those which are secreted and form extracellular gels (MUC2, MUC5AC, MUC5B, and MUC6), ${ }^{6}$ and membrane associated mucins which have membrane anchors and are smaller than the secreted mucins (MUC1, ${ }^{8}$ MUC3 $^{9}$ and MUC 4).${ }^{10}$ Mucin genes are expressed throughout the human gastrointestinal tract in a site specific manner. ${ }^{11}$ This pattern of expression has been studied for the entire gut with the exception of the oesophagus.

Mucin histochemistry has also been used to investigate metaplastic oesophageal epithelium. ${ }^{12-17}$ Barrett's oesophagus is the eponymous term used to describe a condition with malignant potential where the lower oesophagus becomes lined with columnar epithelium as a result of chronic gastro-oesophageal reflux. Although there are three types of columnar epithelium - namely, gastric fundic, junctional

Abbreviations used in this paper: DEPC, diethylpyrocarbonate; PAS/AB, periodic acid Schiff/alcian blue; HID/AB, high iron diamine/alcian blue; PBS, phosphate buffered solution. 
cardia-type, and specialised intestinal epithelium, ${ }^{18}$-it is now accepted that adenocarcinoma arises only from the specialised intestinal-type of metaplasia. ${ }^{19}$ Risk factors for the development of adenocarcinoma include a long segment of Barrett's oesophagus (greater than $8 \mathrm{~cm}),{ }^{20}$ the presence of ulceration, and recognition of dysplasia. ${ }^{21}$

Jass first suggested that mucin histochemistry could be used to establish if a pattern of mucin staining in Barrett's oesophagus may be associated with a greater risk of progression to adenocarcinoma. ${ }^{14}$ Several authors have suggested that expression of sulphomucin is associated with an increased malignant potential. ${ }^{12}{ }^{14}{ }^{15}$ However, Rothery found that $74 \%$ of biopsies of Barrett's oesophagus had evidence of sulphomucin and thus concluded that detection did not help to identify those at risk of progressing to adenocarcinoma. ${ }^{16}$ It has also been claimed that $O$-acetylation is associated with increased risk of malignancy but again this is not clearly established. ${ }^{17}$ The lack of consensus for a link between histochemical findings and clinical outcome has meant that histochemistry is not routinely used to assess prognosis.

It is known that the pattern of mucin gene expression may change in the gastrointestinal tract in conjunction with metaplasia, dysplasia, and malignant transformation. ${ }^{22-24}$ We wished to investigate if different patterns of MUC gene expression are associated with different stages in the multistep process of carcinogenesis. Therefore, we examined mucin gene expression (presence of mRNA and translated protein product) in the normal, metaplastic, and neoplastic oesophagus.

\section{Patients and materials}

Archived paraffin embedded sections of histologically corroborated Barrett's oesophagus from a six month period in 1997 were assessed. All endoscopic biopsies of the oesophagus were taken at least $5 \mathrm{~cm}$ above the gastrooesophageal junction.

Eighteen samples had a corroborative diagnosis of Barrett's oesophagus. ${ }^{25}$ These were taken from areas of velvety mucosa, endoscopically diagnosed as Barrett's oesophagus, situated at least $5 \mathrm{~cm}$ above the gastro-oesophageal junction. Histology showed a specialised-type mucosa characterised by an epithelial lining which included columnar epithelium showing a poorly developed brush border, villous architecture, and goblet cells. In addition, eight samples taken from the normal oesophagus lined by stratified squamous epithelium, eight samples of cardiac-type mucosa from areas identified endoscopically as Barrett's mucosa (henceforth referred to as gastric metaplasia), six cases of high grade dysplasia, and six cases of invasive adenocarcinoma of the lower oesophagus were studied $(n=46$; median age 68 years (range 34-91), male to female ratio 29:17).

All tissues were treated in a strictly RNAase free manner as previously described. ${ }^{26}$ Sections $(4 \mu \mathrm{m})$ were cut from paraffin embedded archived material using a clean baked micro- tome and floated onto $0.1 \%$ diethylpyrocarbonate (DEPC; Sigma, St Louis, Missouri, USA) in distilled water and mounted on baked Histogrip coated slides.

\section{CONTROL SECTIONS}

Control tissues taken from gastric fundus, intestinal metaplasia of the stomach, bronchus, salivary gland, ileum, and colon, with previously described MUC gene expression patterns, ${ }^{11}$ were included with each batch of sections for histochemistry, immunohistochemistry, and in situ hybridisation.

\section{HISTOCHEMISTRY}

Tissue sections from each specimen were stained in a standard fashion with haematoxylin and eosin, periodic acid Schiff/alcian blue (PAS/AB), high iron diamine/alcian blue (HID/ $\mathrm{AB})$, and mild PAS with and without potassium hydroxide saponification ${ }^{27}$ to confirm the diagnosis, localise tissue structures, and assess mucin histochemistry.

IMMUNOHISTOCHEMISTRY

Method for MUC2, MUC5AC, MUC5B, and MUC6

Polyclonal rabbit antimucin antibodies were used. These were LUM2-3 (MUC2), ${ }^{28}$ LUM5-1 (MUC5AC), ${ }^{28}$ M5B, ${ }^{29}$ and GPEP24 (MUC6; supplied by Dr I Carlstedt, Lund University, Lund, Sweden). Tissue sections were deparaffinised through three changes of xylene and then rehydrated through a series of decreasing concentrations of ethanol solutions to distilled water. Antigen retrieval was performed by pressure cooking at $121^{\circ} \mathrm{C}$ for 120 seconds in $10 \mathrm{mM}$ citrate buffer, $\mathrm{pH} 6.0$, and then left to cool at room temperature for 20 minutes. Sections for MUC2 immunohistochemistry were reduced by incubating at $37^{\circ} \mathrm{C}$ in a solution of $10 \mathrm{mM}$ dithiothreitol and $10 \mathrm{mM}$ Tris/ $\mathrm{HCl}$ in distilled water at $\mathrm{pH} 8.0$ for 30 minutes. Endogenous peroxidase activity was blocked in 3\% (v/v) hydrogen peroxidase in distilled water for 20 minutes and washed in phosphate buffered solution (PBS) for five minutes. Slides were incubated overnight with the primary antibody (dilution used: LUM2-3 at 1:3000; LUM5-1 at 1:800; M5B at 1:2500, and GPEP24 at 1:1000). Sections were washed three times for five minutes in PBS and incubated with secondary reagent, 1:100 goat antirabbit horseradish peroxidase conjugate (Dako, High Wycombe, Bucks, UK) in PBS for one hour at room temperature. Tissues were washed three times in PBS. Development was in $0.6 \mathrm{mg} / \mathrm{ml}$ 3-3 diaminobenzidine $/ 0.03 \%$ (v/v) hydrogen peroxide in PBS. Sections were rinsed in water, counterstained with haematoxylin, dehydrated through a series of increasing concentrations of ethanol solutions, and mounted under coverslips.

\section{Method for MUC1 and MUC4}

Monoclonal mouse antimucin antibodies were used. These were BC2 (MUC1) ${ }^{30}$ and M4.275 (MUC4). ${ }^{31}$ Sections were dewaxed, rehydrated, and pressure cooked as described above. Endogenous peroxidase activity was 
blocked by incubating sections in a solution of $20 \%(\mathrm{v} / \mathrm{v})$ methanolic peroxide, $0.1 \%$ sodium azide, and $1 \%$ hydrogen peroxide solution for 10 minutes. Non-specific antibody binding was blocked by incubating sections first in $4 \%$ commercial non-fat skim milk powder in PBS for 15 minutes and then in 10\% normal (nonimmune) goat serum for 15 minutes. Primary antibody (dilutions used: BC 2 at 1:400 and M4.275 at 1:200) was applied for one hour followed by three washes of PBS. Secondary biotinylated goat antimouse antibody (Amersham Life Science, Amersham, Bucks, UK) was applied for 30 minutes followed by three washes of PBS. Sections were then incubated with a 1:50 dilution of streptavidin-horseradish peroxidase conjugate (Amersham, UK) in PBS for 30 minutes. Sections were developed in diaminobenezidine solution, counterstained, and mounted as described above. No suitable anti-MUC 3 antibody was available for the study.

\section{Negative controls}

The primary antibody was omitted as a negative control to test the specificity of the antimucin antibodies for each section.

\section{IN SITU HYBRIDISATION}

The technique of in situ hybridisation used was first described by Scott-Young et al in $1986^{32}$ and modified by Myerscough et al. ${ }^{26}$ Briefly, tissue sections were deparaffinised in xylene and rehydrated through a series of decreasing concentrations of ethanol solutions to distilled $0.1 \%$ DEPC treated water. Sections were digested with proteinase $\mathrm{K}$ (Boehringer Mannheim, Lewes, East Sussex, UK) $10 \mu \mathrm{g} / \mathrm{ml}$ in $50 \mathrm{mM}$ Tris/ $\mathrm{HCl} \mathrm{pH} 7.5$ for 20 minutes at $37^{\circ} \mathrm{C}$ and rinsed in PBS. Tissues were prehybridised by treatment with $0.1 \mathrm{M}$ triethanolamine, $0.25 \%(\mathrm{v} / \mathrm{v})$ acetic anhydride in $0.9 \%(\mathrm{w} / \mathrm{v})$ saline for 10 minutes, and then dehydrated through a series of increasing concentrations of ethanol solutions, delipidated in chloroform, washed in $95 \%$ ethanol, and then air dried. Hybridisation was performed by incubating tissue sections with $60 \mu \mathrm{l}$ of hybridisation buffer (all chemicals from Sigma, St Louis, Missouri, USA, unless otherwise stated), $1 \times$ (v/v) Denhardt's solution $(0.02 \% \mathrm{w} / \mathrm{v}$ ficoll (type 400 ), w/v polyvinylpyrrolidine, $0.02 \%$ $\mathrm{w} / \mathrm{v}$ bovine serum albumin (fraction $\mathrm{V}$ ), $50 \%$ $(\mathrm{v} / \mathrm{v})$ deionised formamide, $10 \%(\mathrm{v} / \mathrm{v})$ dextran sulphate, $60 \mathrm{mM}$ sodium citrate dihydrate, 0.6 $M$ sodium chloride, $0.5 \mathrm{mg} / \mathrm{ml}$ sheared salmon sperm DNA, $12.50 .25 \mathrm{mg} / \mathrm{ml}$ yeast tRNA, and $0.1 \%$ DEPC) containing $50 \mathrm{mM}$ dithiothreitol and $2 \times 10^{5}$ counts per minute $\left[{ }^{35} \mathrm{~S}\right]$ labelled probe. Sections were coverslipped and hybridised for 16 hours at $45^{\circ} \mathrm{C}$ in a humidity chamber. Slides were then washed several times in saline sodium citrate solution ( $15 \mathrm{mM}$ sodium citrate, $0.6 \mathrm{M}$ sodium chloride solution, $\mathrm{pH}$ 7.0). Slides were finally rinsed and air dried.

Slides were dipped in $40 \%(\mathrm{v} / \mathrm{v})$ K5 gel emulsion (Kodak, Ilford, UK) with $0.15 \%$ $(\mathrm{v} / \mathrm{v})$ glycerol in distilled water in a narrow glass chamber for five seconds and dried in air for one hour. Exposure was for three weeks in a desiccation chamber in the dark at $4^{\circ} \mathrm{C}$ after which sections were developed, counterstained with Giemsa solution, fixed, and mounted under coverslips.

Oligonucleotide probe labelling

Complementary 48-mer DNA oligonucleotide probes to the unique tandem repeat domains of the mucin genes MUC1 to MUC6 were used. ${ }^{112633} 34$ The oligonucleotides were 3' end labelled using a terminal deoxynucleotidyltransferase kit (Boehringer Mannheim) with ${ }^{35} \mathrm{~S}$-deoxy-adenosine triphosphate (Amersham) and were purified with a Quick Nucleotide Removal kit (Qiagen Ltd, Crawley, West Sussex, UK).

Negative controls

Controls included: (a) exclusion of probes from hybridisation buffer, (b) RNAse (50 $\mu \mathrm{g} / \mathrm{ml}$ ) pretreatment, (c) competition with 50-fold excess of the unlabelled irrelevant mucin probes, (d) competition with 50 times excess of labelled irrelevant probes, and (e) substitution of mucin probe by $\beta$-actin mRNA probe.

SCORING

All sections were examined by two independent assessors. Concordance between observers was $90 \%$. When there was disagreement between observers the average was taken. Each section was scored according to the predominant cell type labelled and the intensity of labelling from 0 (no staining) to 3 (strong staining). The results were expressed semiquantitatively for each histological group as the number of sections positively labelled, the predominant cell type labelled, and the average score of the positively labelled cells.

\section{Results}

THE NORMAL OESOPHAGUS

Staining with PAS/AB revealed that the submucosal glands of the oesophagus contained a mixture of neutral and acid mucins. HID/AB staining showed that $75 \%$ of cells within the submucosal glands contained sulphomucin. There was no evidence of $O$-acetylation of sialic acid residues on staining by mild PAS with and without saponification.

Results for MUC gene expression in control tissues were similar to previously published data. ${ }^{11}$ Results for MUC gene expression were divided into secreted and membrane bound mucins and are shown in tables 1 and 2, respectively. There was excellent correlation between immunohistochemistry and in situ hybridisation results. MUC5B was very strongly and specifically expressed in the oesophageal submucosal glands on both in situ hybridisation and immunohistochemistry (fig 1A, B). In one specimen a gland was noted between the stratified squamous epithelium and the muscularis mucosae that expressed MUC6 but not MUC5B. MUC1 and MUC4 mRNA were found expressed in the mid layer of the stratified squamous epithelium (fig 1C, $1 \mathrm{E}$, respectively). Their relevant protein core was found in the more superficial layers (fig 
Table 1 Results for expression of the secreted mucin genes (MUC2, MUC5AC, MUC5B, and MUC6)

\begin{tabular}{|c|c|c|c|c|c|c|c|c|c|c|c|c|c|c|c|}
\hline \multirow[b]{2}{*}{ Histological diagnosis } & \multirow[b]{2}{*}{$n$} & \multirow[b]{2}{*}{ Age } & \multirow[b]{2}{*}{$M: F$} & \multicolumn{3}{|c|}{$M U C 2$} & \multicolumn{3}{|c|}{$M U C 5 A C$} & \multicolumn{3}{|c|}{$M U C 5 B$} & \multicolumn{3}{|c|}{ MUC6 } \\
\hline & & & & $S$ & $G$ & $G l$ & $S$ & $G$ & $G l$ & $S$ & $G$ & $G l$ & $S$ & $G$ & $G l$ \\
\hline \multicolumn{16}{|l|}{ In situ hybridisation } \\
\hline Normal oesophagus & 8 & 73 & $5: 3$ & - & - & - & - & - & - & - & - & $\begin{array}{l}+++ \\
(8 / 8)\end{array}$ & - & - & $\begin{array}{l}++ \\
(1 / 8)\end{array}$ \\
\hline Gastric metaplasia & 8 & 57 & $4: 4$ & - & - & - & $\begin{array}{l}+++ \\
(8 / 8)\end{array}$ & - & $\begin{array}{l}++ \\
(8 / 8)\end{array}$ & - & - & - & - & - & $\begin{array}{l}+++ \\
(7 / 8)\end{array}$ \\
\hline Barrett's oesophagus & 18 & 68 & $11: 7$ & - & $\begin{array}{l}+++ \\
(18 / 18)\end{array}$ & - & $\begin{array}{l}+++ \\
(17 / 18)\end{array}$ & - & $\begin{array}{l}+ \\
(17 / 18)\end{array}$ & - & - & - & - & - & $\begin{array}{l}+++ \\
(18 / 18)\end{array}$ \\
\hline $\begin{array}{l}\text { Dysplastic Barrett's } \\
\text { oesophagus }\end{array}$ & 6 & 72 & $4: 2$ & $\begin{array}{l}+ \\
(1 / 6)\end{array}$ & $\begin{array}{l}+ \\
(4 / 6)\end{array}$ & - & $\begin{array}{l}+ \\
(6 / 6)\end{array}$ & - & $\begin{array}{l}+ \\
(6 / 6)\end{array}$ & - & - & - & - & - & $\begin{array}{l}+ \\
(5 / 6)\end{array}$ \\
\hline Adenocarcinoma & 6 & 72 & $5: 1$ & - & - & - & - & - & - & - & - & - & $\begin{array}{l}+ \\
(3 / 6)\end{array}$ & - & - \\
\hline \multicolumn{16}{|l|}{ Immunohistochemistry } \\
\hline Normal oesophagus & 8 & 73 & $5: 3$ & - & - & - & - & - & - & - & - & $\begin{array}{l}+++ \\
(8 / 8)\end{array}$ & - & - & $\begin{array}{l}++ \\
(1 / 8)\end{array}$ \\
\hline Gastric metaplasia & 8 & 57 & $4: 4$ & - & - & - & $\begin{array}{l}+++ \\
(8 / 8)\end{array}$ & - & $\begin{array}{l}++ \\
(8 / 8)\end{array}$ & - & - & - & - & - & $\begin{array}{l}+++ \\
(8 / 8)\end{array}$ \\
\hline Barrett's oesophagus & 18 & 68 & $11: 7$ & - & $\begin{array}{l}+++ \\
(18 / 18)\end{array}$ & - & $\begin{array}{l}+++ \\
(18 / 18)\end{array}$ & - & $\begin{array}{l}++ \\
(18 / 18)\end{array}$ & - & - & - & - & - & $\begin{array}{l}+++ \\
(17 / 18)\end{array}$ \\
\hline $\begin{array}{l}\text { Dysplastic Barrett's } \\
\text { oesophagus }\end{array}$ & 6 & 72 & $4: 2$ & $\begin{array}{l}+ \\
(1 / 6)\end{array}$ & $\begin{array}{l}+ \\
(3 / 6)\end{array}$ & - & $\begin{array}{l}+ \\
(6 / 6)\end{array}$ & - & $\begin{array}{l}+ \\
(6 / 6)\end{array}$ & - & - & - & - & - & $\begin{array}{l}+ \\
(5 / 6)\end{array}$ \\
\hline Adenocarcinoma & 6 & 72 & $5: 1$ & - & - & - & - & - & - & - & - & - & $\begin{array}{l}+ \\
(3 / 6)\end{array}$ & - & - \\
\hline
\end{tabular}

S, superficial cell layer; G, goblet cells; Gl, deep glands or crypts.

Scoring: average intensity of positively labelled cells: +++ strong; ++ moderate; + weak; - absent.

Values in parentheses denote the number of positively labelled specimens.

1D, F). Labelling of MUC1 was much fainter than that of MUC4 by both in situ hybridisation and immunohistochemistry. MUC4 was also found in duct epithelial cells but not in the secretory epithelial cells within the glands.

\section{BARRETT'S OESOPHAGUS}

Histochemistry

Specialised Barrett's oesophagus had neutral mucins in the glands and superficial columnar cells. Acid mucins were noted in the superficial columnar cells and goblet cells. In particular, $12 / 18$ specimens stained positively for sulphomucin. This occurred mainly in the goblet cells. Four of the six specimens of high grade dysplasia stained for sulphomucin. Only $1 / 6$ adenocarcinomas stained positive for sulphomucin, although in four of these cases there was surrounding intestinal metaplasia that stained positive for sulphomucin. Staining with mild PAS with or without saponification showed that there was no detectable $O$-acetylation of sialic acid residues.
There was no correlation between histochemical staining and mucin gene expression pattern.

\section{Secreted mucins}

Results of labelling for secreted mucins are shown in table 1 . Staining showed excellent correlation between immunohistochemistry and in situ hybridisation.

MUC2-There was no MUC2 expression in gastric metaplasia of the oesophagus. Strong MUC2 labelling was noted in the goblet cells in Barrett's oesophagus (fig 2A, B). In the samples showing dysplasia, only $3 / 6$ showed evidence of weak MUC2. There was no MUC2 expression in adenocarcinoma.

$M U C 5 A C$ - Strong staining of MUC5AC was noted in the columnar epithelium of both gastric metaplasia of the lower oesophagus and in Barrett's oesophagus (fig 2D, E). No MUC5AC was seen in goblet cells. Dysplastic tissues showed mild to moderate MUC5AC

Table 2 Results for expression of the membrane associated mucins MUC1, MUC3, and MUC4

\begin{tabular}{|c|c|c|c|c|c|c|c|c|c|c|}
\hline \multirow[b]{2}{*}{ Histological diagnosis } & \multirow[b]{2}{*}{$n$} & \multicolumn{3}{|l|}{$M U C 1$} & \multicolumn{3}{|l|}{$M U C 3$} & \multicolumn{3}{|l|}{$M U C 4$} \\
\hline & & $S$ & $G$ & $G l$ & $S$ & $G$ & $G l$ & $S$ & $G$ & $G l$ \\
\hline \multicolumn{11}{|l|}{ In situ hybridisation } \\
\hline Normal oesophagus & 8 & $+(7 / 8)$ & - & - & - & - & - & $++(8 / 8)$ & - & - \\
\hline Gastric metaplasia & 8 & $++(8 / 8)$ & - & $+(8 / 8)$ & - & - & - & $+(8 / 8)$ & - & $+(8 / 8)$ \\
\hline $\begin{array}{l}\text { Specialised Barrett's } \\
\text { oesophagus }\end{array}$ & 18 & $+(18 / 18)$ & - & $+(3 / 18)$ & $++(18 / 18)$ & - & - & $+(15 / 18)$ & - & $+(15 / 18)$ \\
\hline $\begin{array}{l}\text { Dysplastic Barrett's } \\
\text { oesophagus }\end{array}$ & 6 & $++(3 / 6)$ & - & $+(3 / 6)$ & $+(4 / 6)$ & - & - & $++(3 / 6)$ & - & $+(3 / 6)$ \\
\hline Adenocarcinoma & 6 & $++(4 / 6)$ & - & - & $+(1 / 3)$ & - & - & $++(3 / 6)$ & - & - \\
\hline \multicolumn{11}{|l|}{ Immunohistochemistry } \\
\hline Normal oesophagus & 8 & $++(7 / 8)$ & - & - & $\mathrm{n} / \mathrm{a}$ & $\mathrm{n} / \mathrm{a}$ & $\mathrm{n} / \mathrm{a}$ & $++(8 / 8)$ & - & - \\
\hline Gastric metaplasia & 8 & $+(8 / 8)$ & - & $+(8 / 8)$ & $\mathrm{n} / \mathrm{a}$ & $\mathrm{n} / \mathrm{a}$ & $\mathrm{n} / \mathrm{a}$ & $+(8 / 8)$ & - & $+(8 / 8)$ \\
\hline $\begin{array}{l}\text { Specialised Barrett's } \\
\text { oesophagus }\end{array}$ & 18 & $+(10 / 18)$ & - & $+(1 / 18)$ & $\mathrm{n} / \mathrm{a}$ & $\mathrm{n} / \mathrm{a}$ & $\mathrm{n} / \mathrm{a}$ & $+(17 / 18)$ & - & $+(16 / 18)$ \\
\hline $\begin{array}{l}\text { Dysplastic Barrett's } \\
\text { oesophagus }\end{array}$ & 6 & $++(3 / 6)$ & - & $+(3 / 6)$ & $\mathrm{n} / \mathrm{a}$ & $\mathrm{n} / \mathrm{a}$ & $\mathrm{n} / \mathrm{a}$ & $++(3 / 6)$ & - & $+(3 / 6)$ \\
\hline Adenocarcinoma & 6 & $++(4 / 6)$ & - & - & $\mathrm{n} / \mathrm{a}$ & $\mathrm{n} / \mathrm{a}$ & $\mathrm{n} / \mathrm{a}$ & $++(4 / 6)$ & - & - \\
\hline
\end{tabular}

n/a, not available; S, superficial cell layer; G, goblet cells; Gl, deep glands or crypts.

Scoring: average intensity of positively labelled cells: +++ strong; ++ moderate; + weak; - absent.

Values in parentheses denote number of positively labelled specimens. 

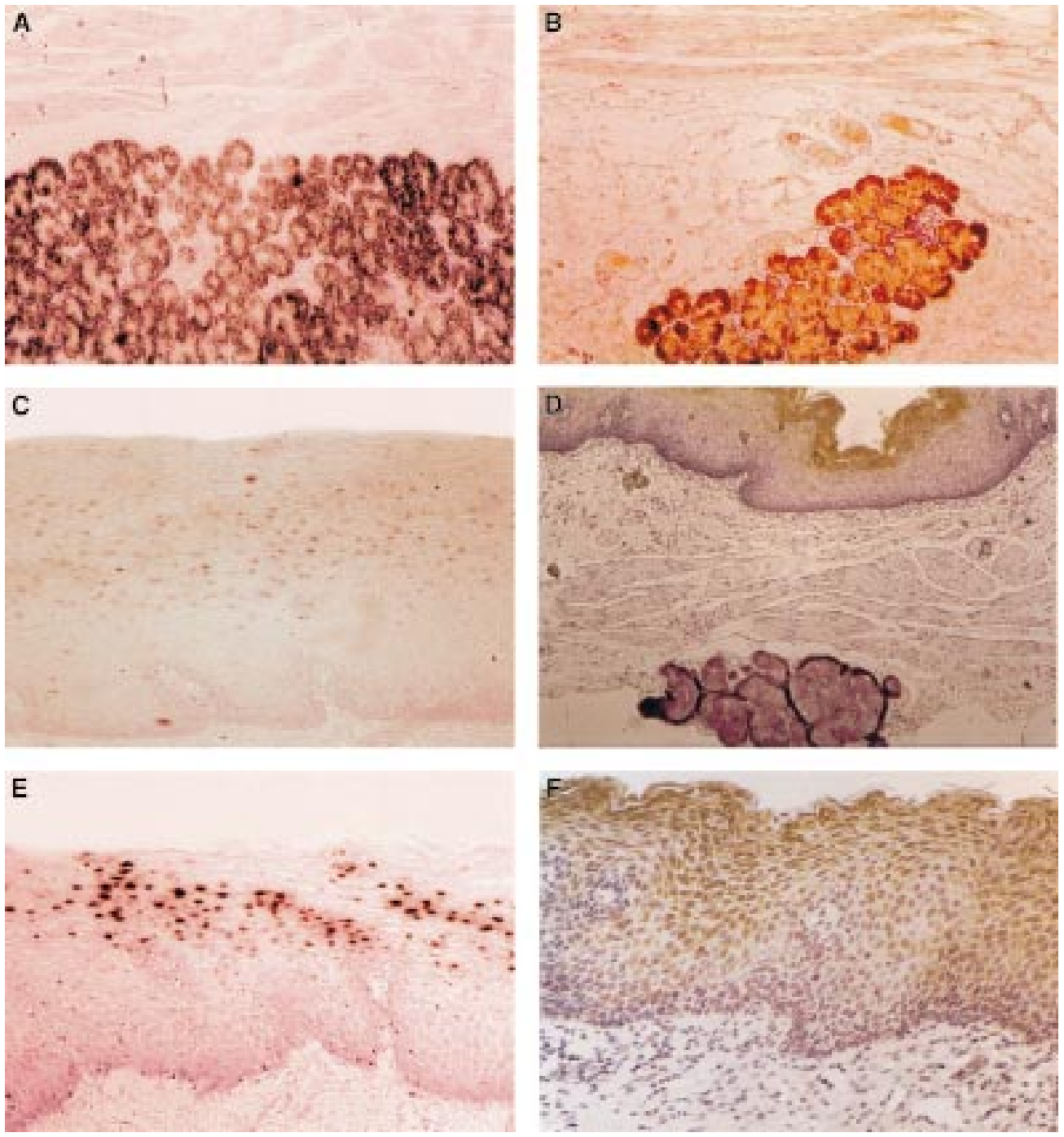

Figure 1 Photomicrographs of the normal oesophagus. $(A, B)$ Normal submucosal gland; $(C-F)$ normal stratified squamous epithelium. (A) MUC5B (in situ hybridisation $\times 200$ ). (B) MUC5B (immunohistochemistry $\times 200)$. (C) MUC1 mRNA expressed in the mid layer of the stratified squamous epithelium (in situ hybridisation $\times 200)$. (D) MUC protein product in the superficial layer of the stratified squamous epithelium but none in the gland (immunohistochemistry $\times 100)$. (E) MUC4 $\mathrm{mRNA}$ in the mid layer of the stratified squamous epithelium (in situ hybridisation $\times 200)$. (F) MUC4 protein product in the superficial layer of the stratified squamous epithelium (immunohistochemistry $\times 200$ ).

mRNA and protein but invasive adenocarcinoma showed no MUC5AC.

MUC5B-MUC5B was not found in any sample of gastric metaplasia, Barrett's oesophagus, or adenocarcinoma on either in situ hybridisation or immunohistochemistry.

MUC6-Gastric metaplasia and specialised Barrett's glands expressed MUC6 mRNA and protein in cardiac-type glands at the base of the crypts (fig $2 \mathrm{~F}$ ). There was weak staining of MUC6 in 4/6 dysplastic tissues and in 3/6 cases of adenocarcinoma.

\section{Membrane bound mucins}

Results of labelling for membrane bound mucins are shown in table 2. Staining showed excellent correlation between immunohistochemistry and in situ hybridisation.

MUC1-Mild labelling of MUC1 was associated predominantly in the superficial epithelium of both gastric and specialised intestinal metaplasia. In a small number of specimens labelling was also noted in glands.
MUC1 mRNA expression was demonstrated in all 18 specimens of Barrett's oesophagus but protein product was noted in only $10 / 18$ specimens. There was moderate MUC1 staining in 3/6 sections of high grade dysplasia (fig $2 \mathrm{G}$ ) and in 4/6 sections of adenocarcinoma found by both in situ hybridisation and immunohistochemistry.

MUC3-MUC3 immunohistochemistry was not performed (see methods). In this study MUC 3 was expressed in the superficial columnar cells of specialised intestinal metaplasia (fig 2C) but not in gastric metaplasia of the oesophagus. Dysplastic tissue showed only mild MUC3 expression in 4/6 samples. One case of adenocarcinoma showed mild MUC3 expression.

MUC4-Mild MUC4 mRNA and protein was detected in specialised Barrett's epithelium in the basal region of columnar cells of the surface epithelium and in the crypt epithelium. In three sections of Barrett's oesophagus no 

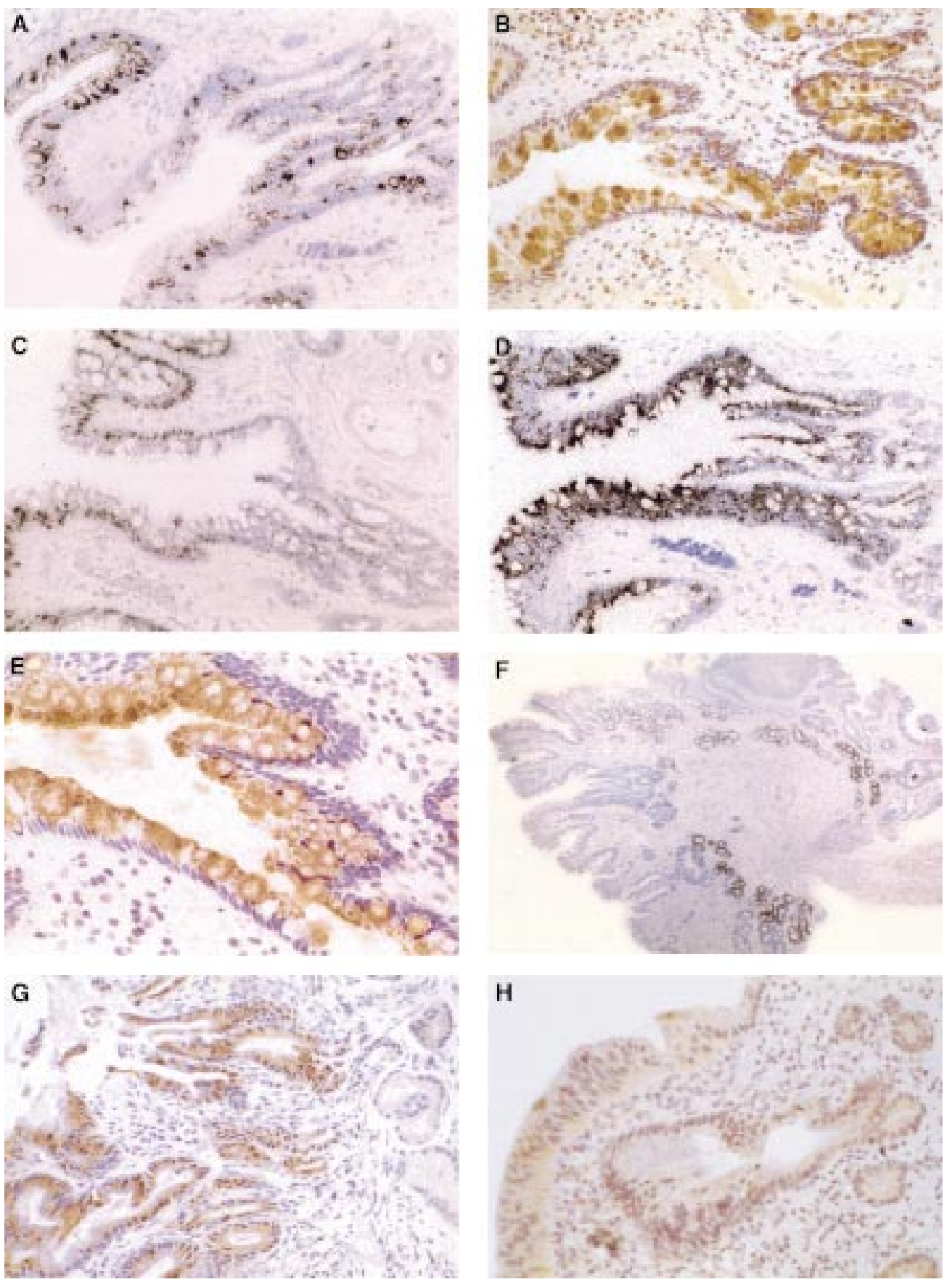

Figure 2 Photomicrographs of Barrett's oesophagus $(A-F)$ and Barrett's oesophagus with high grade dysplasia $(G, H)$ (A) MUC2 $m R N A$ expression in goblet cells (in situ hybridisation $\times 200$ ). (B) MUC2 protein product in goblet cells (immunohistochemistry $\times 200$ ). (C) MUC3 $m R N A$ expression in the superficial columnar epithelium (in situ hybridisation $\times 200$ ). (D) MUC5AC $m R N A$ expression in the columnar epithelium and crypts (in situ hybridisation $\times 200)$. (E) MUC5AC protein product in the columnar epithelium and crypts (immunohistochemistry $\times 200$ ). (F) MUC6 mRNA expression in the columnar epithelium of Barrett's glands (in situ hybridisation $\times 50$ ). (G) MUC1 protein product in the columnar epithelium of high grade dysplasia (immunohistochemistry $\times 100)$. (H) MUC4 protein product in the columnar epithelium of high grade dysplasia (immunohistochemistry $\times 200$ ).

labelling was seen by in situ hybridisation but was noted with immunohistochemistry. This may be due to the absence of mRNA synthesis or a technical error. In $3 / 6$ cases of dysplasia (fig $2 \mathrm{H}$ ) and $3 / 6$ cases of adenocarcinoma there was moderate expression of MUC4.

\section{Discussion}

We have described for the first time the profile of currently known mucin genes of normal and Barrett's oesophagus. Both exhibited a unique pattern of mucin gene expression in the alimentary tract. A strength of the study is that both mRNA expression and translation to protein product were analysed and found to correlate well for mucin gene expression.

We found that MUC5B was the predominant mucin secreted by the submucosal glands of the normal oesophagus. In 1910, Goetsch differentiated between the superficial glands of the lower oesophagus and the true submucosal glands of the oesophagus. ${ }^{35}$ We found that the 
superficial glands of the lower oesophagus (that is, lying above the muscularis mucosae) expressed only MUC6 but not MUC5B.

MUC5B is also produced by salivary and bronchial glands. ${ }^{11}$ Salivary and oesophageal submucosal gland secretions have a common purpose, namely to lubricate the epithelial lining for the passage of luminal contents. It is therefore not surprising to find that they both express MUC5B. This is consistent with evidence from other areas of the alimentary tract that MUC gene expression combined with tissue specific glycosylation is adapted to specific functions. ${ }^{36}$ However, the stomach produces MUC5AC and MUC6 to protect its cells from the effects of gastroduodenal refluxate. Assuming that the mucin gene structure is related to its function, it is puzzling that despite $40 \%$ of the population describing symptoms of gastro-oesophageal reflux ${ }^{37}$ the normal oesophagus does not produce the same protective mucin genes as the stomach.

The lining of the oesophagus is stratified squamous epithelium and hence would not be expected to secrete mucin. In 1976, Hopwood et al used the PAS stain with diastase digestion and HID/AB to demonstrate that the "intercellular space of the functional cell layer contained neutral and sialic acid-rich mucopolysaccharides". ${ }^{2}$ We have shown that the membrane bound mucins, MUC1 and MUC4, are expressed in the stratified squamous epithelium both on in situ hybridisation and immunohistochemistry; their expression in stratified squamous tissues have previously been described in the vagina and cervix. ${ }^{39}$

It is possible that, in some patients, reflux oesophagitis is due to inadequate mucus protection of the epithelium. This is suggested clinically by the finding that certain patients have severe oesophageal damage despite having only mild reflux noted on pH monitoring. ${ }^{41}$ Furthermore, a significant proportion of patients will fail to achieve complete healing despite the use of powerful antisecretory medication. ${ }^{42} 43$ Studies by Namiot et al have confirmed that patients with severe reflux oesophagitis have an impaired ability to produce oesophageal mucus. ${ }^{44}$ It is not known at present if abnormalities in the mucin gene expression pattern may be responsible for an inadequate mucus barrier. However, now that we have described the mucin genes expressed by the normal oesophagus, it would be interesting to investigate if there is altered expression of the membrane bound mucins MUC1 and MUC4, or the secreted mucin MUC5B in patients with reflux oesophagitis.

Since the first description of the histochemistry of Barrett's oesophagus ${ }^{14}$ there have been many attempts to accurately identify whether particular mucin staining patterns are associated with an increased risk of malignancy, with no consensus of opinion. ${ }^{12}{ }^{15-17}$ Our study suggests that cardiac-type gastric mucosa of the lower oesophagus (referred to as gastric metaplasia) has an identical mucin gene profile to normal gastric mucosa-that is, strong expression of MUC5AC in the superficial columnar cells and MUC 6 in the glands with low grade expression of MUC1 and MUC4. However, in specialised Barrett's oesophagus where the mucosa histologically resembles intestinal mucosa, there is strong expression of MUC2 in the goblet cells and MUC3 in the superficial columnar epithelium (that is, the normal intestinal mucin pattern) and MUC5AC and MUC6 (the gastric mucins). This is a pattern already described for incomplete intestinal metaplasia of the stomach ${ }^{22}$ and is further evidence that Barrett's oesophagus and incomplete intestinal metaplasia of the stomach are the same condition and represent differentiation into a unique epithelial lineage. We have shown that the normal oesophagus secretes MUC5B, in common with salivary glands, but neither gastric nor intestinal type mucins. Dixon et al showed that there was an adherent mucus gel layer of $90 \mu \mathrm{m}$ thickness present in Barrett's oesophagus that was not present in the normal stratified squamous epithelium. ${ }^{45}$ Hence the "metaplastic epithelium" may reflect an adaptive response to new luminal environment. Jankowski suggests that incomplete intestinal-type metaplasia may be a response to reflux of gastroduodenal contents and in particular bile acids. ${ }^{46}$ Our studies would support such a theory as Barrett's epithelium produces both MUC5AC and MUC6 associated with protection from gastric acid and MUC2 and MUC3 associated with protection from bile.

Further evidence for Barrett's epithelium having a role in protection and repair comes from studies on trefoil peptides. Hanby and colleagues $^{47}$ showed that the trefoil peptides TFF1 and TFF2 (formerly known as pS2 and hSP, respectively) are expressed within Barrett's oesophagus. More recently, Labouvie and colleagues, ${ }^{48}$ using immunohistochemistry, showed that TFF1 and MUC5AC are coexpressed in the superficial columnar epithelium of Barrett's oesophagus. The biological functions of the trefoil peptides are not fully understood but there is good evidence that they are associated with mucosal repair and, furthermore, may act synergistically with mucins to protect epithelial tissues. ${ }^{49-52}$ Further work is needed to investigate if trefoil peptides interact with the other mucins that this study has shown to be strongly expressed by Barrett's epithelium.

With greater degrees of dysplasia, mucin gene changes continue to occur. The secreted mucin genes MUC2, MUC5AC, and MUC6 were downregulated and expression became more heterogeneous. The membrane bound mucins MUC1 and MUC4 showed a more complicated pattern with upregulation in some cases. Interestingly, MUC3, which has now been shown to be membrane bound ${ }^{9}$ responded to dysplastic change by downregulation in the same way as the other "secreted mucins". These changes partly mirror the histological changes associated with dysplasiathat is, reductions in cytoplasmic volume and mucin production. Upregulation of MUC1 and MUC4 found in the dysplastic and neoplastic oesophagus in our study has already 
been described in the bronchus, breast, colon, stomach, and pancreas. ${ }^{232453}$

Abnormal expression of oncogenes has also been reported in Barrett's epithelium. These include the tumour suppressor gene $\mathrm{p} 53,{ }^{54-56}$ the proto-oncogene c-erbB- $2,{ }^{57}$ and primary cell nuclear antigen. ${ }^{54}$ In particular, tumours expressing c-erbB-2 have been associated with a poor five year prognosis and increased tendency to metastasise. ${ }^{57}$ In Barrett's oesophagus and adenocarcinoma the c-erbB2 protein is found in the membrane. ${ }^{57} \mathrm{An}$ interaction has been shown between c-erB-2 and MUC4 in the rat. ${ }^{58}$ It is not known if there is an association between oncogenes and the membrane bound mucins MUC1 and MUC4 in humans. It may also be that mucin expression per se can contribute to increased cell growth and metastatic ability.

We have demonstrated unique mucin gene profiles for the normal oesophagus and Barrett's oesophagus and highlighted interesting potential avenues of future investigation. Further work is necessary to show if a primary abnormality in mucin gene expression of the normal oesophagus may be responsible for some patients developing reflux oesophagitis. With regard to Barrett's oesophagus it is not clear if the mucin gene changes are related to an adaptive response to reflux or reflect the genetic instability associated with a preneoplastic condition. Further investigation may elucidate the pathway of differentiation in the oesophagus that causes squamous epithelium to be replaced by columnar epithelium leading eventually to adenocarcinoma. Prospective studies are required to ascertain if this alteration in mucin gene expression can be used to detect those patients with Barrett's oesophagus at the risk of progression to dysplasia and potentially adenocarcinoma.

Mr GS Arul is the Vandervell research fellow of the Royal Colege of Surgeons of England. This work was also funded by a grant from the Medical Research Committee of the Special Trustees for the United Bristol Healthcare Trust. The author wish to thank Dr I Carlstedt (Lund University, Lund, Sweden) for the generous gift of the GPEP 24 antimucin antibody, Dr JK Sheehan and Dr Thornton (University of Manchester, Manchester, UK) for the generous gift of anti-MUC5B antibodies, and Dr M McGukin and Dr MD Walsh (University of Queensand Dr M McGukin and Dr MD Walsh (University of Queensland, Brisbane, Australia) for the generous gift of $\mathrm{BC} 2$ and antibodies were available through a European Union Biomed 2 grant, contract number BMH4-CT98-3222.

1 Hopwood D, Coghill G, Sanders DS. Human oesophageal submucosal glands. Their detection, mucin, enzyme and secretory protein content. Histochemistry 1986;86:107-12.

2 Hopwood D, Logan KR, Coghill G, et al. Histochemical studies of the muco-substances and the lipids in the normal studies of the muco-substances and the lipids in the norma
human oesophageal epithelium. Histochem $\mathcal{F} 1977 ; 9: 153-$ 61 .

Corfield AP. The role of mucins in the gastrointestinal tract: an overview with emphasis on nutrition. In: Renner B, Sawatzki G, eds. New perspectives in infant nutrition. New York: Thieme Medical Publications, 1995:57-65.

4 Sariosek J, McCallum RW. The evolving appreciation of esophageal mucosal protection in the pathophysiology of gastroesophageal reflux disease. F Pract Gastroenterol 1994; 18:20J-20Q

5 Namiot Z, Sariosek J, Marinkiewicz M, et al. Declined human esophageal mucin secretion in patients with severe reflux esophagitis. Dig Dis Sci 1994;39:2523-9.

6 Gum JR. Mucins: their structure and biology. Biochem Soc Trans 1995;23:795-9.

7 Sheehan JK, Thornton DJ, Howard M, et al. Biosynthesis of the MUC2 mucin: evidence for a slow assembly of fully the MUC2 mucin: evidence for a slow assemb

8 Gendler SJ, Spicer AP. Epithelial mucin genes. Annu Rev Physiol 1995;57:607-34.
9 Williams SJ, Munster DJ, Quin RJ, et al. The MUC 3 gene encodes a transmembrane mucin and is alternatively encodes a transmembrane mucin and is alter
spliced. Biochem Biophys Commun 1999;261:83-9.

10 Moniaux N, Nollet S, Porchet N, et al. Complete sequence of the human mucin MUC4: a putative cell membraneassociated mucin. Biochem f 1999;338:325-33.

11 Audie JP, Janin A, Porchet N, et al. Expression of human mucin genes in respiratory, digestive and reproductive tracts ascertained by in-situ hybridisation. $\mathcal{f}$ Histochem Cytochem 1993;41:1479-85.

12 Peuchmaur M, Potet F, Goldfain D. Mucin histochemistry of the columnar epithelium of the oesophagus (Barrett's oesophagus): a prospective biopsy study. $\mathcal{F}$ Clin Pathol 984;37:607-10.

13 Jass JR, Filipe MI. The mucin profiles of normal gastric mucosa, intestinal metaplasia and its variants and gastric carcinoma. Histochem $\mathcal{F}$ 1981;13:931-9.

14 Jass JR. Mucin histochemistry of columnar epithelium of the oesophagus: a retrospective study. F Clin Pathol 1981;34: 866-87.

15 Duchatelle V, Potet F, Bara J, et al. Mucin immunohistochemistry of the columnar epithelium. Virchows Arch 1989; 414:359-63.

16 Rothery GA, Patterson JE, Stoddard CJ, et al. Histological and histochemical changes in the columnar lined (Barrett's) oesophagus. Gut 1986;27:1062-8.

17 Lapertosa G, Baracchini P, Fulcheri E. Mucin histochemical analysis in the interpretation of Barrett's esophagus. Results of a multicenter study. The Operative Group for the Study of Esophageal Precancer. Am f Clin Pathol 1992; 98:61-6.

18 Paull A, Trier JS, Dalton MD, et al. The histologic spectrum of Barrett's esophagus. N Engl F Med 1976;295:476-80.

19 Thompson JJ, Zinsser KR, Enterline HT. Barretts metaplasia and adenocarcinoma of the esophagus and gastroesophageal junction. Hum Pathol 1983;14:42-61.

20 Iftikar SY, James PD, Steele RJC, et al. Length of Barrett's oesophagus: an important factor in the development of dysplasia and adenocarcinoma. Gut 1992;33:1155-8.

21 Miros M, Kerlin P, Walker N. Only patients with dysplasia progress to adenocarcinoma in Barrett's oesophagus. Gut 1991;32:1441-6.

22 Reis CA, David L, Correa P, et al. Intestinal metaplasia of human stomach displays distinct patterns of mucin (MUC1, MUC2, MUC5AC, and MUC6) expression. Cancer Res 1999;59:1003-7.

23 Ho SB, Shekels LL, Toribara NW, et al. Mucin gene expression in normal, preneoplastic, and neoplastic human gastric epithelium. Cancer Res 1995;55:2681-90.

24 Balague C, Audie JP, Porchet N, et al. In situ hybridization shows distinct patterns of mucin gene expression in normal, benign, and malignant pancreas tissues. Gastroenterology 1995;109:953-64.

25 Shepherd NA, Biddlestone LR. The histopathology and cytopathology of Barrett's oesophagus. CPD Bull Cell Pathol 1999;1:39-44.

26 Myerscough N, Warren BF, Gough M, et al. Expression of mucin genes in ulcerative colitis. Biochem Soc Trans 1995;23:536S.

27 Filipe MI. The histochemistry of intestinal mucins: changes in disease. In: Whitehead $\mathrm{R}$, ed. Gastrointestinal and oesophageal physiology. Edinburgh: Churchill Livingstone, 1989:65-89.

28 Hovenberg HW, Davies JR, Hermann A, et al. MUC 5AC, but not MUC 2, is a prominent mucin in respiratory secretions. Glycoconj F 1996;13:839-47.

29 Thornton DJ, Howard $\mathrm{M}$, Khan $\mathrm{N}$, et al. Identification of two glycoforms of the MUC 5B mucin in human respiratory mucus - evidence for a cysteine-rich sequence repeated within the molecule. F Biol Chem 1997;272:9561-

30 Xing P, Prenzoska J, Quelch K, et al. Second generation anti-MUC1 peptide monoclonal antibodies. Cancer Res 1992;52:2310-17.

31 Xing PX, Prenzoka J, Apostolopoulos V, et al. Monoclonal antibodies to a MUC 4 peptide react with lung caner. Int $\mathcal{F}$ Oncol 1997;11:289-95.

32 Scott-Young W, Bonner TI, Brann MR. Mesencephalic dopamine neurons regulate the expression of neuropeptide mRNAs in the rat forebrain. Proc Natl Acad Sci USA 1986; 83:9827-31.

33 Toribara NW, Roberton AM, Ho SB, et al. Human gastric mucin. Identification of a unique species by expression cloning. F Biol Chem 1993;268:5879-85.

34 Lancaster CA, Peat N, Duhig T, et al. Structure and expression of the human polymorphic epithelial mucin gene: an expressed VNTR unit. Biochem Biophys Res Commun 1990; 173:1019-29.

35 Goetsch E. The structure of the mamalian oesophagus. $\mathrm{Am}$ f Anat 1910;10:1-40.

36 Corfield AP, Warren BF, Bartolo DC, et al. Mucin changes in ileoanal pouches monitored by metabolic labelling and histochemistry. Br f Surg 1992;79:1209-12.

37 Nebel OT, Fornes MF, Castell DO. Symptomatic gastroesophageal reflux: incidence and precipitating factors. Dig Dis Sci 1976;34:1329-35.

38 Holloway RH, Orenstein SR. Gastroesophageal reflux disease in adults and children. Baillieres Clin Gastroenterol 1991;5:347-70

39 Gipson IK, Ho SB, Hill JA, et al. Mucin genes expressed by human female reproductive tract epithelia. Biol Reprod 1997;56:999-1011. 
40 Schlesinger PK, Donahue PE, Schmid B, et al. Limitations of 24 hour $\mathrm{pH}$ monitoring in the hospital setting. Gastroenterology 1985;89:797-804.

41 Watson RG, Tham TC, Johnston BT, et al. Double blind cross-over placebo controlled study of omeprazole in the treatment of patients with reflux symptoms and physiological levels of acid reflux - the "sensitive oesophagus". Gut 1997;40:587-90.

42 Dehn TC, Shepherd HA, Colin-Jones D, et al. Double blind comparison of omeprazole $(40 \mathrm{mg}$ od) versus cimetidine $(400 \mathrm{mg} \mathrm{qd})$ in the treatment of symptomatic erosive reflux oesophagitis, assessed endoscopically, histologically and by $24 \mathrm{~h}$ pH monitoring. Gut 1990;31:509-13.

43 Sharma BK, Walt RP, Pounder RE, et al. Optimal dose of oral omeprazole for maximal 24 hour decrease of intra-gastric acidity. Gut 1984:35:957-64.

44 Namiot Z, Sariosek J, Rourk M, et al. Human esophageal secretion: mucosal response to luminal acid and pepsin. Gecretion: mucosal response to lumi

45 Dixon J, Pearson JP, Griffin M, et al. A mucus gel barrier is present in Barrett's oesophagus but is not present in present in Barrett's oesophagus but is not pr
normal oesophagus. Gut 1999;44(suppl 1):A109.

46 Jankowski J. Gene expression in Barrett's mucosa: acute and chronic adaptive responses in the oesophagus. Gut 1993;34:1649-50.

47 Hanby AM, Jankowski JA, Elia G, et al. Expression of the trefoil peptides pS2 and human spasmolytic polypeptide (hSP) in Barrett's metaplasia and the native oesophageal epithelium: delineation of epithelial phenotype. $\mathcal{F}$ Pathol 1994;173:213-19.

48 Labouvie C, Machado JC, Carneiro F, et al. Differential expression of mucins and trefoil peptides in native epithelium, Barrett's metaplasia and squamous cell carcinoma of the oesophagus. F Cancer Res Clin Oncol 1999;125:71-6.

49 Dignass A, Lynch-Devaney K, Kindon H, et al. Trefoil peptides promote epithelial migration through a transforming growth factor beta-independent pathway. $\mathcal{f}$ Clin Invest 1994;94:376-83.

50 Wright NA, Poulsom R, Stamp G, et al. Trefoil peptide gene expression in gastrointestinal epithelial cells in inflammatory bowel disease. Scand $\mathcal{F}$ Gastroenterol Suppl 1992;193: 76-82.

51 Konturek PC, Brzozowski T, Konturek SJ, et al. Role of spasmolytic polypeptide in healing of stress-induced gastric lesions in rats. Regul Pept 1997;68:71-9.

52 Playford RI, Marchbank T, Goodlad RA, et al. Transgenic mice that overexpress the human trefoil peptide pS2 have an increased resistance to intestinal damage. Proc Natl Acad an increased resistance to in
Sci USA 1996;93:2137-42.

53 Ho SB, Niehans GA, Lyftogt C, et al. Heterogeneity of mucin gene expression in normal and neoplastic tissues. Cancer Res 1993;53:641-51.

54 Kim R, Clarke MR, Melhem MF, et al. Expression of p53, PCNA, and C-erbB-2 in Barrett's metaplasia and adenocarcinoma. Dig Dis Sci 1997;42:2453-62.

55 Gleeson CM, Sloan JM, McManus DT, et al. Comparison of p53 and DNA content abnormalities in adenocarcinoma of the oesophagus and gastric cardia. Br $\mathcal{F}$ Cancer 1998;77: $277-86$.

56 Jaskiewicz K, Louw J, Anichkov N. Barrett's oesophagus: mucin composition, neuroendocrine cells, $\mathrm{p} 53$ protein, cellular proliferation and differentiation. Anticancer Res 1994; 14:1907-12.

57 Jankowski J, Coghill G, Hopwood D, et al. Oncogenes and onco-suppressor gene in adenocarcinoma of the oesophagus. Gut 1992;33:1033-8.

58 Price-Schiavi SA, Carraway KL. Post-transcriptional regulation of a milk membrane protein, the sialomucin complex (ascites sialoglycoprotein (ASGP)-1/ASGP-2, rat MUC 4), by transforming growth factor beta. $\mathcal{F}$ Biol Chem 1998;273: 35228-37.

\section{8th United European Gastroenterology Week}

The UEGW abstract book (Gut 2000;47(suppl III)) has again been produced as a CD-ROM and can be found attached to the inside back cover of this issue. 